\title{
PENERAPAN MODEL PEMBELAJARAN TWO STAY TWO STRAY (TSTS) DALAM MENINGKATKAN HASIL BELAJAR SISWA KELAS Vc PADA TEMA 7 PERISTIWA DALAM KEHIDUPAN DI SD NEGERI 19 KENDARI
}

\author{
Suci Ramadhani Rudin ${ }^{1)}$, Muhamad Abas ${ }^{1)}$, La Ode Rafiuddin $\mathrm{R}^{1)}$ \\ ${ }^{1)}$ Jurusan Pendidikan Guru Sekolah Dasar \\ FKIP Universitas Halu Oleo \\ email: suciiramadhani14@gmail.com, muhamadabas750@gmail.com, rafiuddinr90@gmail.com
}

\begin{abstract}
Abstrak: Tujuan dari penelitian ini adalah "Untuk meningkatkan hasil belajar siswa kelas $\mathrm{V}_{\mathrm{c}}$ SDN 19 Kendari melalui penerapan model pembelajaran Two Stay Two Stray (TSTS) pada tema 7 Peristiwa Dalam Kehidupan ". Prosedur penelitian yaitu: (a) perencanaan (planning), (b) pelaksanaan tindakan (action), (c) observasi dan evaluasi (observation and evaluation), dan (d) refleksi (reflection). Jenis data yaitu data kualitatif dan data kuantitatif. Data kualitatif diperoleh melalui lembar observasise dangkan data kualitatif melalui tes hasil belajar. Hasil penelitian menunjukan bahwa pada siklus I terdapat 16 dari 28 siswa yang telah mencapai persentase ketuntasan klasikal atau 57,14\% dengan nilai rata-rata hasil belajar siswa adalah 68,3. Sedangkan pada siklus II mengalami peningkatan yaitu terdapat 23 dari 28 siswa yang telah mencapai persentase ketuntasan belajar atau $82,14 \%$ dengan nilai rata-rata hasil belajar siswa adalah 79,03 .
\end{abstract}

Kata Kunci: Model pembelajaran Two Stay Two Stray (TSTS), Hasil Belajar IPS

\section{THE APPLICATION OF TWO STAY TWO STRAY (TSTS) LEARNING MODELS IN IMPROVING THE LEARNING OUTCOMES OF CLASS VC STUDENTS IN 7 THEMES OF LIFE IN SD NEGERI 19 KENDARI}

\begin{abstract}
The purpose of this research is to improve student learning outcomes in grade VC Elementary School 19 Kendari through Two Stay Two Stray (TSTS) learning model theme 7 Peristiwa Dalam Kehidupan. Research procedures of this research were (a) planning (planning), (b) implementing the actions (actions), (c) observation and evaluation (observation and evaluation), and (d) reflection (reflection). The types of data were qualitative and quantitative data. Qualitative data was obtained through observation sheets while qualitative data was through learning outcomes tests. The results showed that in cycle I there were 16 out of 28 students who had achieved a classical or $57.14 \%$ survival percentage with the average value of student learning outcomes 68,3. While the II cycle has increased in that there are 23 out of 28 students who have reached a percentage of learning or $82.14 \%$ with the average value of student learning outcomes is 79,03.
\end{abstract}

Keywords: Two Stay Two Stray (TSTS) learning models, learning outcomes IPS 
Jurnal Ilmiah Pembelajaran Sekolah Dasar

Volume 2 Nomor 1 - Februari 2020, e-ISSN 2656-0402

Available online at:http://ojs.uho.ac.id/index.php/jipsd

\section{Pendahuluan}

Pendidikan adalah cara untuk mencerdaskan bangsa. Perkembangan jaman saat ini menuntut adanya sumber daya manusia yang berkualitas sehingga mampu bersaing dengan negara lain yang telah maju. Pendidikan mempunyai peranan yang sangat penting dalam menciptakan sumber daya manusia yang berkualitas. Pendidikan yang berkualitas akan berpengaruh pada kemajuan di berbagai bidang, disamping mengusahakan pendidikan yang berkualitas, Pemerintah perlu melakukan pemerataan pendidikan dasar bagi setiap Warga Negara Indonesia, agar mampu berperan serta dalam memajukan kehidupan bangsa Sekolah menurut Tjangkana, (2014).

Seorang guru yang profesional dituntut untuk dapat menampilkan keahliannya sebagai guru di depan kelas. Komponen yang harus dikuasai adalah menggunakan bermacam - macam model pembelajaran yang bervariasi dapat menarik minat belajar. Dalam proses pendidikan di sekolah, kegiatan belajar merupakan kegiatan yang paling pokok. Keberhasilan pencapaian tujuan pendidikan banyak bergantung kepada bagaimana proses belajar yang dialami oleh peserta didik. Dalam proses belajar mengajar guru selalu melibatkan peserta secara aktif untuk mengembangkan kemampuannya dalam berpikir rasional, kritis, dan kreatif.

Realitas proses pembelajaran yang dilakukan oleh sebagian guru masih menggunakan pola pembelajaran yang konvensional atau metode ceramah, dimana peserta didik lebih banyak mendengarkan penjelasan guru guru di depan kelas. Dalam hal ini dalam melainkan pada suatu saat peserta didik akan menjadi bosan apabila hanya guru sendiri yang berbicara, sedangkan mereka duduk diam mendengarkan. Sehingga hasil belajar siswa akan berdampak pada suatu pembelajaran.

Pembelajaran adalah kegiatan yang secara sadar dan sengaja dilakukan guru, sehingga tingkah laku siswa yang meliputi aktivitas dan pola pikir siswa berubah ke arah yang lebih baik, proses ini bertujuan untuk membantu siswa dalam memperoleh berbagai pengalaman dan dari pengalaman tersebut kualitas tingkah laku siswa akan meningkat menurut Darsono dalam Ismawati \& Hindarto, (2011).

Ketidak berhasilan dalam proses belajar mengajar untuk mencapai ketuntasan bahan tidak dapat dikembalikan pada satu faktor, tetapi pada beberapa faktor yang terlibat dalam proses sebuah kegiatan belajar dan mengajar. Faktor tersebut menunjukkan murid yang belajar, kegiatan yang terlibat dalam proses, dan jenis kesulitan yang dialami oleh murid. Sehingga penggunaan model pembelajaran erat kaitannya dengan tahapan berfikir siswa.

Berdasarkan dokumen guru kelas $V_{c}$ SDN 19 Kendari tahun ajaran 2018/2019 berupa hasil ulangan tengah semester pada tema 7 peristiwa dalam kehidupan, menunjukkan dari 28 orang siswa hanya 6 siswa atau 21\% yang mendapat nilai di atas KKM dan 22 orang siswa atau $78 \%$ tidak tuntas atau berada di bawah kriteria ketuntasan minimal dengan nilai KKM yaitu 75 dan nilai rata-rata yang diperoleh siswa tersebut adalah 62,7. Rendahnya nilai siswa diakibatkan oleh rasa bosan ketika belajar dan kurangnya aktivitas siswa didalam kelas.

Menyikapi kondisi tersebut diatas, maka perlu dilakukan upaya untuk memperbaiki dan meningkatkan hasil belajar siswa. Salah satu upaya yang dapat dilakukan untuk memperbaiki dan meningkatkan hasil belajar siswa kelas $\mathrm{V}_{\mathrm{c}}$ SDN 19 Kendari adalah melalui model pembelajaran inovatif, salah satunya adalah model pembelajaran Two Stay Two Stray (TSTS).

Model pembelajaran kooperatif Two Stay Two Stray (TSTS) digunakan untuk proses belajar karena model pembelajaran Two Stay Two Stray (TSTS) merupakan sistem pembelajaran kelompok dengan tujuan agar siswa dapat saling bekerjasama, bertanggung jawab, saling membantu memecahkan masalah dan saling mendorong untuk berprestasi dan dapat melatih siswa untuk bersosialisasi dengan baik.

Menurut Suprijono dalam Syamsiah \& Gunansyah, (2014) pembelajaran kooperatif adalah konsep yang lebih luas meliputi semua jenis kerja kelompok termasuk bentuk-bentuk yang lebih dipimpin oleh guru atau diarahkan oleh guru. Jadi di penelitian ini peneliti lebih condong ke arah pembelajaran kooperatif (cooperative learning). Forming (pembentukan); Functioning (pengaturan); 
Formating (perumusan); Fermentin (penyerapan). Dalam menerapkan suatu model pembelajaran, pasti terdapat kelebihan-kelebihan dan kelemahan. Menurut Trianto model pembelajaran kooperatif ini mempunyai kelebihan-kelebihan yaitu: dapat meningkatkan motivasi belajar siswa; siswa dapat berkomunikasi dengan temannya; dapat meningkatkan keaktifan dalam pembelajaran; dapat meningkatkan pemahaman dalam prestasi belajar.

Menurut Lie dalam Qorry Aulya Rohmana, Dkk (2016) model Two Stay Two Stray (TSTS) merupakan salah satu model pembelajaran kooperatif untuk menghadapi kemampuan heterogen siswa yang dilakukan dengan membentuk kelompok yang bersifat heterogen kemudian saling bertukar informasi dengan kelompok lain.

Berdasarkan uraian di atas masalah dalam penelitian ini adalah "Apakah Penerapan Model Pembelajaran Two Stay Two Stray (TSTS) Dapat Meningkatkan Hasil Belajar Siswa Kelas Vc Pada Tema 7 Peristiwa Dalam Kehidupan di SD Negeri 19 Kendari?"

\section{Metode Penelitian}

Jenis penelitian ini adalah penelitian tindakan yang dilakukan oleh guru dalam kelas sebagai bentuk penelitian yang dilakukan oleh guru dikelasnya sendiri melalui refleksi diri dengan tujuan untuk memperbaiki kinerjanya sehingga hasil belajar siswa meningkat Aqib dkk dalam Nur Afni, Amiruddin, dan Ahmad Mahmud, (2014). Penelitian ini dilaksanakan di kelas IV SDN 19 Kendari yang berlokasi Jl. Pattimura, No. 50, Kel. Watulondo, Kec. Puuwatu Kota Kendari Provinsi Sulawesi Tenggara pada semester genap tahun ajaran 2019/2020. Subjek penelitian ini adalah siswa kelas V $_{C}$ SDN 19 Kendari yang terdaftar dan aktif pada semester genap tahun ajaran 2019/2020 sebanyak 28 siswa dan guru kelas $\mathrm{V}_{\mathrm{C}}$ SDN 19 Kendari. Faktor yang diteliti dalam penelitian ini adalah 1)faktor siswa, 2)Faktor guru dan 3) faktor hasil belajar. Penelitian tindakan kelas ini dilaksanakan dalam 2 (dua) siklus.

Adapun prosedur penelitian ini menggunakan desain Kemmis \& Taggart yang masingmasing terdiri atas tahap-tahap: kegiatan (a) perencanaan (planning), (b) pelaksanaan tindakan (action), (c) observasi dan evaluasi (observation and evaluation), dan (d) refleksi (reflection) Kemmis \& Taggart dalam Manik et al., (2016). Jenis data yaitu data kualitatif dan data kuantitatif. Data kualitatif diperoleh melalui observasi, menggunakan lembar observasi sedangkan data kuantitatif diperoleh melalui tes setiap akhir siklus tindakan. Data kualitatif dianalisis secara deskriptif kualitatif. Data dimaksud kan untuk melihat proses pelaksanaan pembelajaran yang dilakukan oleh guru ketika menggunakan model pembelajaran Two Stay Two stray (TSTS). Sedangkan data kuantitatif dianalisis secara deskriptif kuantitatif. Analisis data yang digunakan dalam penelitian ini terbagi dua yaitu analisis kualitatif dan analisis kuantitatif. Data kualitatif akan dianalisis secara deskriptif kualitatif berdasarkan hasil observasi yang dilakukan. Sedangkan data kuantitatif dianalisis secara kuantitatif berdasarkan hasil tes pada setiap akhir siklus tindakan.

\section{Hasil Penelitian}

1. Aktivitas Guru

Tabel 1. Rekapitulasi Aktivitas Guru Siklus I dan Siklus II

\begin{tabular}{llcc}
\hline \multirow{2}{*}{ No } & Aspek yang di amati & \multicolumn{2}{c}{ Skor } \\
\cline { 3 - 4 } & & Siklus 1 & Siklus 2 \\
\hline 2 & Persiapan & 4 & 4 \\
\hline 3 & Presentase Guru & 1 & 2 \\
\hline 4 & Kegiatan Kelompok & 7 & 8 \\
\hline 5 & Evaluasi Kelompok dan Penghargaan & 4 & 6 \\
\hline \multicolumn{2}{r}{ Jumlah } & 4 & 24 \\
\hline & Rata-Rata & 20 & 12 \\
\hline & Presentase & 10 & $100 \%$ \\
\hline
\end{tabular}


Aktivitas belajar dan pembelajaran pada siklus 1. Guru sudah menggunakan langkah-langkah pembelajaran Two Stay Two Stray (TSTS), namun belum efektif, jadi guru melakukan refleksi. Refleksi merupakan proses atau tahap dalam penelitian tindakan kelas dimana bertujuan untuk memperbaiki kesalahan yang terjadi pada setiap akhir pembelajaran. Berdasarkan hasil observasi dan evaluasi pada pelaksanaan tindakan siklus I baik pertemuan I dan pertemuan II masih jauh dari harapan yang telah ditetapkan sebelumnya, hal ini berdasarkan hasil diskusi antara peneliti dengan guru kelas dimana terlihat beberapa kekurangan saat proses pembelajaran berlangsung baik itu dilakukan oleh guru maupun siswa. Dari hasil observasi, maka beberapa hal yang perlu diperbaiki untuk pelaksanaan pada siklus II adalah sebagai berikut:

a. Guru harus menyampaikan tujuan pembelajaran setiap pertemuan

b. Guru harus lebih memahami bagaimana langkah-langkah menerapkan model pembelajaran dengan menggunakan model pembelajaran Two Stay Two Stray (TSTS).

c. Guru harus menyimpulkan setiap akhir pembelajaran

d. Siswa harus memperhatikan guru menyampaikan pembelajaran

Setelah mengetahui kekurangan yang terjadi pada siklus I baik itu yang dilakukan oleh guru maupun siswa, maka pada pembelajaran siklus II guru akan mencoba meminimalisir kesalahankesalahan yang dilakukan sebelumnya, sehingga hasil belajar dengan menerapkan model Two Stay Two Stray (TSTS) sesuai dengan yang diharapkan yaitu sesuai dengan indikator keberhasilan mencapai $80 \%$.

2. Aktivitas Siswa

Tabel 2. Rekapitulasi Aktivitas Siswa Siklus I dan Siklus II

\begin{tabular}{llcc}
\hline \multirow{2}{*}{ No } & \multirow{2}{*}{ Aspek yang di amati } & \multicolumn{2}{c}{ Skor } \\
\cline { 3 - 4 } & & Siklus 1 & Siklus 2 \\
\hline 1 & Persiapan & 4 & 4 \\
\hline 2 & Presentase Guru & 1 & 2 \\
\hline 3 & Kegiatan Kelompok & 7 & 8 \\
\hline 4 & Formalitas & 4 & 4 \\
\hline 5 & Evaluasi Kelompok dan Penghargaan & 4 & 6 \\
\hline \multicolumn{2}{r}{ Jumlah } & 20 & 24 \\
\hline & Rata-Rata & 10 & 12 \\
\hline & Presentase & $83 \%$ & $100 \%$ \\
\hline
\end{tabular}

\section{Hasil Belajar}

Hasil analisis penelitian pada siklus I terdapat 16 siswa yang telah mencapai nilai $\geq$ 75 dengan ketuntasan sebesar $57,14 \%$ dan 12 or ang siswa atau 42,86\% yang tidak tuntas dan nilai rata-rata yang diperoleh siswa tersebut adalah 67,92. Siklus II terdapat 23 siswa telah mencapai nilai $\geq 75$ dengan ketuntasan sebesar $82,14 \%$. Dan 5 orang siswa $17,86 \%$ yang tidak tuntas dan nilai rata-rata yang diperoleh siswa tersebut adalah 79 .

Tabel 3. Daftar Nilai Hasil Belajar Siswa Siklus I dan Siklus II

\begin{tabular}{cccc}
\hline \multirow{2}{*}{ No } & \multirow{2}{*}{ Pencapaian } & Siklus 1 & Siklus \\
\cline { 3 - 4 } & & 28 orang & 28 orang \\
\hline 1 & Jumlah Siswa & 85 & 86 \\
\hline 2 & Nilai Tertinggi & 40 & 65 \\
\hline 3 & Nilai Terendah & 67,92 & 79 \\
\hline 4 & Nilai Rta-Rata & $57,14 \%$ & $82,14 \%$ \\
\hline 5 & $\%$ Tuntas & $42,86 \%$ & $17,86 \%$ \\
\hline 6 & $\%$ Tidak Tuntas & & \\
\hline
\end{tabular}


Berdasarkan hasil uraian pada siklus I dan II, menunjukan bahwa model pembelajaran Two Stay Two Stray (TSTS) dapat meningkatkan hasil belajar siswa. Hal ini dapat tercapai karena dalam proses pembelajaran, siswa tidak hanya duduk mendengarkan penjelasan dari guru, akan tetapi siswa menyelesaikan sendiri permasalahan yang dihadapi berdasarkan informasi yang didapat dari berbagai sumber. Selain itu siswa juga terlibat langsung dalam proses pembelajaran Two Stay Two Stray (TSTS), mulai tahapan persiapan, presentasi guru, kegiatan kelompok, formalitas, evaluasi dan penghargaan.

\section{Pembahasan}

Berdasarkan hasil evaluasi pada siklus I terhadap hasil belajar siswa menunjukan bahwa dengan melaksanakan model pembelajaran Two Stay Two Stray (TSTS) dapat meningkatkan hasil belajar siswa pada tema 7 peristiwa dalam kehidupan di kelas $V_{C}$ SDN 19 Kendari jika dibandingkan dengan hasil belajar siswa pada tahun ajaran sebelumnya (2018/2019). Peningkatan hasil belajar siswa siklus I dapat dilihat pada gambar 1 berikut ini:

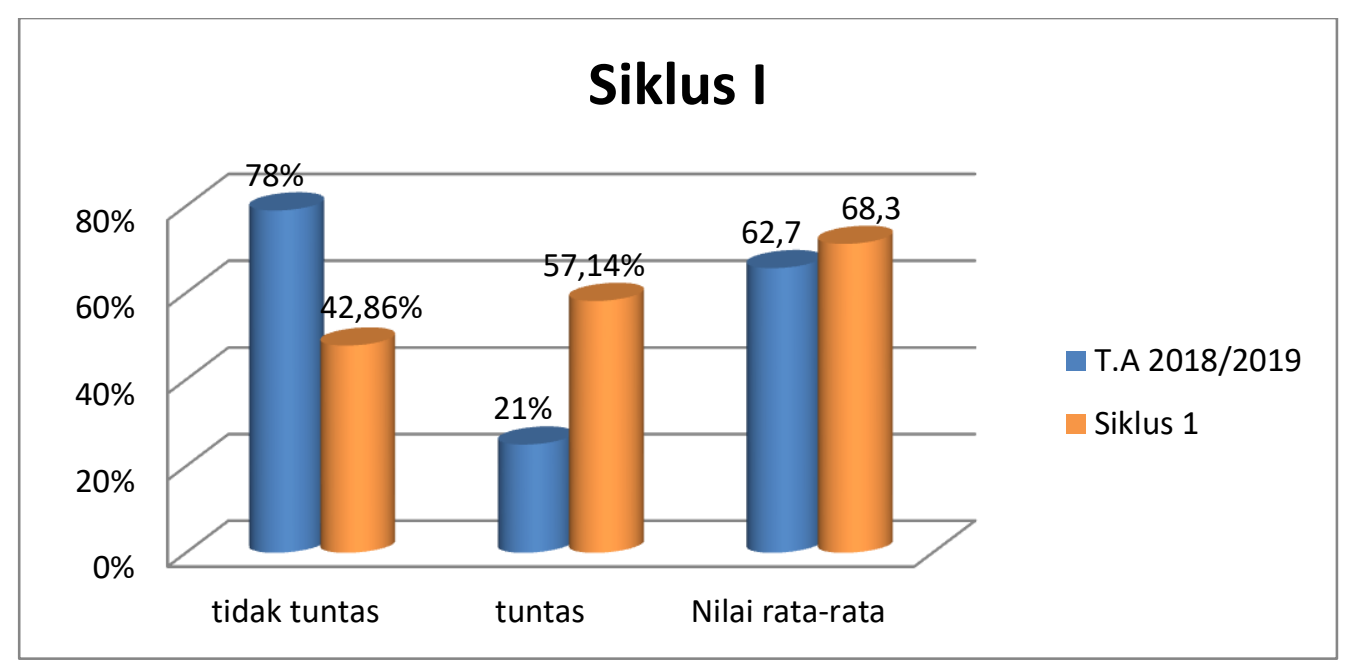

Gambar 1. Peningkatan Hasil Belajar Siswa pada Siklus I

Berdasarkan gambar $1 \mathrm{di}$ atas peningkatan hasil belajar siswa pada siklus I menunjukkan bahwa yang mencapai ketuntasan belajar pada siklus I berjumlah 16 orang siswa dengan persentase sebesar 57,14\% sedangkan, jumlah 12 siswa yang tidak tuntas dengan persentase sebesar 42,14\% dengan nilai rata-rata 68,3. Maka,hasil belajar siswa belum mencapai ketuntasan belajar. Meskipun hasil belajar siswa secara klasikal meningkat namun belum memenuhi indikator kinerja sebesar $80 \%$.

Kemudian peningkatan hasil belajar siswa meningkat pada siklus II untuk lebih jelasnya peningkatan hasil belajar siswa dapat dilihat pada gambar 2 berikut ini: 


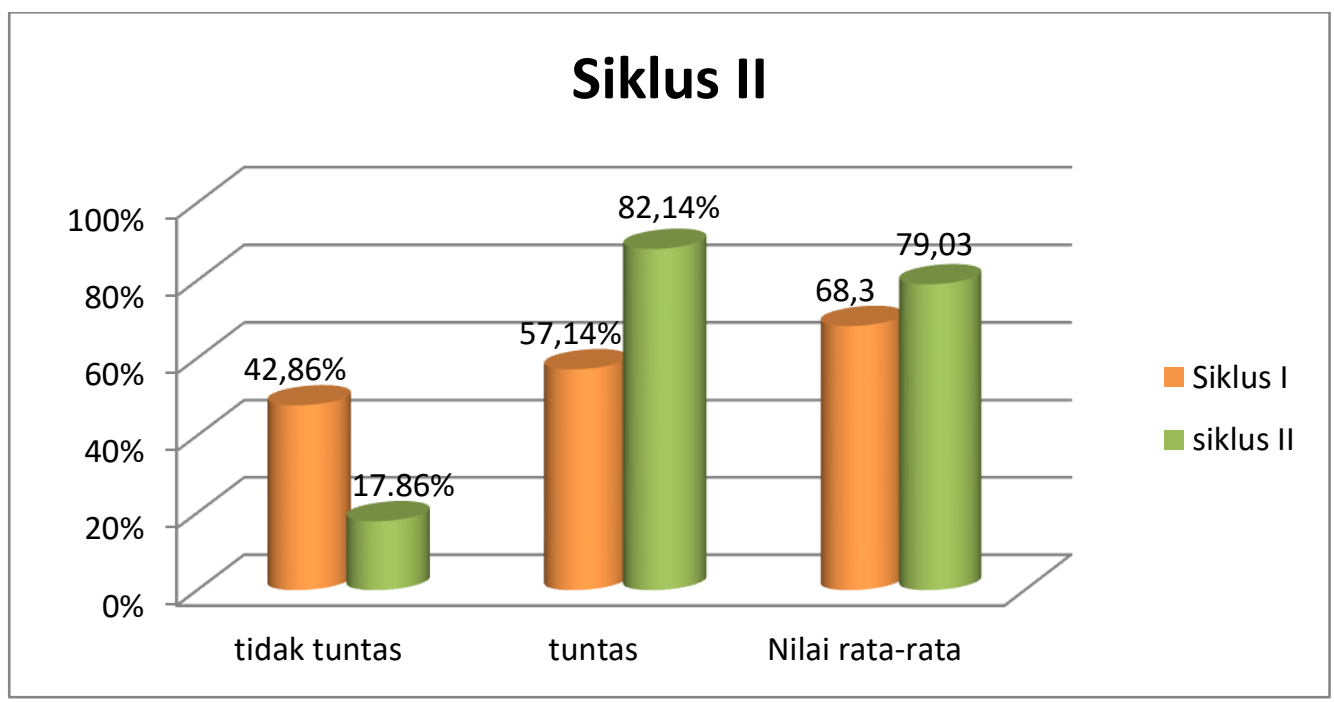

Gambar 2. Peningkatan Hasil Belajar Siswa Pada Siklus II

Berdasarkan gambar 2 di atas menunjukkan bahwa hasil belajar siswa dalam kegiatan pembelajaran mengalami peningkatan pada siklus II. Siswa yang mencapai ketuntasan berjumlah 23 orang dengan persentase ketuntasan sebesar $82,14 \%$ dan siswa yang tidak mencapai ketuntasan berjumlah 5 orang siswa persentase sebesar 17,86\% dengan nilai rata-rata siswa 79,03 dan mengalami kenaikan sebesar 25\%. Dari hasil belajar siswa pada siklus II dapat diketahui bahwa indikator kinerja yang telah ditentukan yaitu $80 \%$ telah tercapai, sedangkan hasil hasil observasi kegiatan pembelajaran sudah terlaksana dengan baik sesuai dengan langka-langka pembelajaran Two Stay Two Stray (TSTS) di kelas Vc SDN 19 Kendari. Peningkatan tersebut dikarenakan penggunaan model pembelajaran Two Stay Two Stray (TSTS) dengan saling bekerja sama, bertanggung jawab, dan saling membantu memecahkan masalah serta dapat mempermudah dalam mengerjakan soal dan dan saling mendapatkan informasi.

Oleh karena itu penerapan model pembelajaran Two Stay Two Stray (TSTS) dapat dikatakan berjalan dengan baik karena siswa dapat dengan mudah memahami pelajaran yang diberikan sehingga sangat antusias dan aktif dalam proses pembelajaran berlangsung. Hasil tindakan tersebut sesuai dengan pendapat menurut Huda dalam Teriana Mardha Hidayat1, Ali Muhson (2018) model Pembelajaran Two Stay Two Stray (TSTS) sebagai sistem pembelajaran dengan tujuan untuk dapat bekerja bersama, bertanggung jawab, saling membantu memecahkan masalah, dan saling mendorong untuk menjadi unggul dan melatih siswa untuk bersosialisasi. Artinya pembelajaran dengan menggunakan model pembelajaran Two Stay Two Stray (TSTS) memberikan peningkatan besar terhadap hasil belajar siswa untuk bisa memecahkan masalah dalam kegiatan pembelajaran. Peneliti dianggap telah berhasil meningkatkan hasil belajar siswa mencapai indicator kinerja yang diharapkan dalam penelitian ini yaitu $80 \%$.

Dari uraian di atas, maka proses pembelajaran dengan menerapkan model pembelajaran Two Stay Two Stray (TSTS) dalam penelitian ini, dikatakan mampu meningkatkan keaktifan setiap siswa dalam proses pembelajaran, menyelesaikan masalah dan saling bekerja sama, serta saling memberikan informasi kepada kelompok lain dan tingginya rasa tanggung jawab satu sama lainnya sehingga hasil belajar siswa dapat ditingkatkan, bukan saja kemampuan kognitifnya tetapi juga kemampuan afektif dan psikomotornya sehingga proses pembelajaran yang dilahirkan benar-benar mencerminkan pembelajaran yang efektif. Dengan demikian penerapan model pembelajaran Two Stay Two Stray (TSTS) dapat meningkatkan hasil belajar siswa Vc pada tema 7 peristiwa dalam kehidupan SD Negeri 19 Kendari meningkat. 
Jurnal Ilmiah Pembelajaran Sekolah Dasar

Volume 2 Nomor 1 - Februari 2020, e-ISSN 2656-0402

Available online at:http://ojs.uho.ac.id/index.php/jipsd

\section{Simpulan}

Berdasarkan hasil penelitian dan pembahasan dapat disimpulkan bahwa dengan menerapkan model pembelajaran Two Stay Two Stray (TSTS) dapat meningkatkan hasil belajar siswa pada tema 7 peristiwa dalam kehidupan di kelas Vc SD Negeri 19 Kendari. Hasil siklus I menunjukkan hasil belajar siswa dari 28 orang siswa, yang tuntas sebanyak 16 orang dengan persentase ketuntasan sebesar $57,14 \%$ dan yang tidak tuntas sebanyak 12 orang dengan persentase sebesar $42,86 \%$ dengan nilai rata-rata hasil belajar siswa adalah 68,3. Pada siklus II mengalami peningkatan yaitu dari 28 orang siswa, yang tuntas sebanyak 23 orang dengan persentase ketuntasan sebesar $82,16 \%$ dan yang tidak tuntas sebanyak 5 orang dengan persentase sebesar 17,86\% dengan nilai rata-rata hasil belajar siswa adalah 79,03. Secara klasikal ketuntasan hasil belajar siswa pada siklus I dan siklus II terjadi peningkatan sebesar 25\%. Oleh karena itu, pada siklus II telah mencapai indikator keberhasilan sebesar $80 \%$ dari jumlah siswa seluruhnya maka hasil belajar siswa pada penelitian ini meningkat.

\section{Daftar Pustaka}

Daryanto. (2018). Penelitian Tindakan Kelas dan Penelitian Tindakan Sekolah.Yogyakarta: Gava Media.

Herawati. (2015). Penerapan Model Pembelajaran Two Stay Two Stray Untuk Meningkatkan Prestasi Belajar Siswa Pada Materi Keliling Dan Luas Lingkaran Di Kelas VI SD Negeri 53 Banda Aceh. Jurnal Peluang. 3(2), 95-105.

I Wayan Subagia, I. G. L. W. (2016). Profil Penilaian Hasil Belajar Siswa. Jurnal Pendidikan Indonesia. 5(1), 39-54.

Ismawati, N., \& Hindarto, N. (2011). Penerapan Model Pembelajaran Kooperatif Dengan Pendekatan Struktural Two Stay Two Stray Untuk Meningkatkan Hasil Belajar Siswa Kelas X Sma. Jurnal Pendidikan Fisika Indonesia, 7(1), 38-41. https://doi.org/10.15294/jpfi.v7i1.1067

Manik, K., Gafur, A., Yogyakarta, U. N. (2016). Harmoni Sosial : Jurnal Pendidikan IPS Volume 3 , No 1 Penerapan Model Two Stay Two Stray Berbantuan Multimedia Untuk Meningkatkan Ativitas Dan Hasil Belajar IPS The Implementation. 3(1), 39-49. Retrieved from https://media.neliti.com/media/publications/61952-ID-none.pdf

Nur Afni, Amiruddin, dan Mahmud A. (2014). Meningkatkan Hasil Belajar Siswa Pada Mata Pelajaran IPS Dengan Menggunakan Metode Diskusi di Kelas IV SDN 12 Biau. Jurnal Kreatif Tadulako. 5(3). 181-196.

Syamsiah, S., \& Gunansyah, G. (2014). Penerapan Model Pembelajaran Kooperatif Tipe Two Stay Two Stray Pada Mata Pelajaran Ips Untuk Meningkatkan Hasil Belajar Siswa Kelas Iv A Sdn Simomulyo 8 Surabaya. Jurnal Pendidikan Guru Sekolah Dasar, 2(1), 1-9. Retrieved from http://jurnalmahasiswa.unesa.ac.id/article/13971/18/article.pdf

Teriana Mardha Hidayat1, Ali Muhson (2018). The Impact of Think Pair Share and Two Stay Two Stray Learning Model Towards Learning Outcomes and Cooperation Ability. 13(1), 119-129.

Tjangkana, I. (2014). Meningkatkan Hasil Belajar Siswa Pada Mata Pelajaran IPS Melalui Penggunaan Peta Konsep di Kelas V SD Inpres 15 Wara Pantoloan. 5(5), 116-123.

Qorry Aulya Rohmana, Nur Widodo, \& Listijo Kapti. (2016). Penerapan Model Pembelajaran TTSTS (Two Stay Two Stray) Dipadu Picture \& Picture Untuk Meningkatkan Keaktifan Dan Hasil Belajar Materi Jaringan Hewan Pada Siswa Kelas XI SMA. Jurnal Pendidikan: Teori, Penelitian, dan Pengembangan. 11(10), 2071-2075. 